\title{
Evidence of a North Atlantic right whale Eubalaena glacialis mating ground
}

\author{
Timothy V. N. Cole ${ }^{1, *}$, Philip Hamilton ${ }^{2}$, Allison Glass Henry ${ }^{1}$, Peter Duley ${ }^{1}$, \\ Richard M. Pace III $^{1}$, Bradley N. White ${ }^{3}$, Tim Frasier ${ }^{4}$
}

${ }^{1}$ NOAA Northeast Fisheries Science Center, 166 Water Street, Woods Hole, Massachusetts 02543, USA

${ }^{2}$ Edgerton Research Laboratory, New England Aquarium, Central Wharf, Boston, Massachusetts 02110, USA

${ }^{3}$ Department of Biology, Trent University, 2140 East Bank Drive, Peterborough, Ontario K8J 7B8, Canada

${ }^{4}$ Department of Biology, Saint Mary's University, 923 Robie Street, Halifax, Nova Scotia B3H 3C3, Canada

\begin{abstract}
The location of mating grounds used by Endangered North Atlantic right whales Eubalaena glacialis has eluded discovery despite centuries of whaling and decades of marine mammal surveys. If this species' gestation duration is similar to the closely related southern right whale E. australis, then conception for the North Atlantic right whale occurs in the boreal winter. Between 2002 and 2008, aerial surveys identified half the North Atlantic population in the central Gulf of Maine between November and January. Generalized linear models indicated that significantly higher proportions of both known fathers and conceptive females were present in this region compared to most other areas seasonally inhabited by right whales. Their presence in the central Gulf of Maine during the estimated conception period strongly suggests that this region is a mating ground for the species. Roseway Basin, on the southwestern Scotian Shelf, also had high proportions of reproductive whales and may be the site of some conceptions if right whale gestation extends to 14 mo.
\end{abstract}

KEY WORDS: Aerial surveys · Conception period · Gulf of Maine - Mating ground · Photo identification · Right whale

\section{INTRODUCTION}

The North Atlantic right whale Eubalaena glacialis is among the most endangered marine mammal species in the world (Reilly et al. 2012), with roughly 500 individuals (Pettis 2012) ranging along the eastern coast of the USA and Canada (Reeves et al. 1978, Winn et al. 1986, IWC 2001a). Mortality from collisions with vessels and entanglement in commercial fishing gear threaten the population's survival (Caswell et al. 1999, Moore et al. 2004, Kraus et al. 2005, Knowlton \& Brown 2007). The population is monitored using photographs of natural markings skin callosities, pigmentation, and scars - that are unique to each individual (Kraus et al. 1986a, Hamil- ton et al. 2007). Extensive aerial and vessel survey effort throughout the right whales' range provides a nearly complete census each year, with estimated annual re-sighting probabilities ranging from 75 to $90 \%$ during the study period (National Marine Fisheries Service unpubl. data).

Intensive study over the last $30 \mathrm{yr}$ has led to many discoveries about right whale habitat, behavior, and demography (e.g. Kraus \& Rolland 2007). However, knowledge of right whales' seasonal distribution remains fragmented, and until recently there was no indication of the location of their mating grounds. In general, most of the population spends the boreal spring and summer on feeding grounds off the northeastern USA and Canadian Maritimes (e.g. Winn et 
al. 1986, Kenney et al. 2001). In late fall or early winter, pregnant females migrate to waters off the southeastern USA to give birth (Kraus et al. 1986b). Most mothers of the year are detected during intensive aerial surveys that are conducted during December through March off the coasts of Florida, Georgia, and South and North Carolina (Kraus et al. 2007). Mothers and calves return to feeding grounds in early spring (Kraus et al. 1986b, Hamilton \& Mayo 1990), and calves continue to accompany their mother for a year following birth (Hamilton \& Cooper 2010).

After weaning, mothers 'rest' for a year or more, presumably rebuilding energy stores prior to conceiving again. This rest period is variable, and 8 or more years may pass between the detected calving events of some females (Hamilton et al. 1998, Knowlton et al. 1994, Kraus et al. 2001, 2007). Adult females are not typically seen on the calving grounds the winter before or after calving, and both resting and pregnant females are sighted significantly less often on the known feeding grounds than males, juvenile females, and lactating mothers (Brown et al. 2001).

Sightings data, and analyses of mitochondrial DNA (mtDNA), suggest that there is seasonal subdivision of the population in relation to summer feeding ground use by mothers. Specifically, nursing mothers tend to show preference for different feeding grounds, with some females that preferentially bring their calves to the Bay of Fundy and other females that preferentially bring their calves to another - as yet unidentified-summer feeding area or areas (Schaeff et al. 1993, Malik et al. 1999). This differential summer feeding area use by mothers is passed from mothers to their offspring and results in significant differentiation of maternally inherited mitochondrial haplotypes between calves born to mothers with different habitat preferences (Schaeff et al. 1993, Malik et al. 1999). However, despite this seasonal subdivision regarding feeding ground use, nuclear markers (microsatellites) do not show differentiation between these 2 groups, which suggests 1 interbreeding population. Little is known about exchange with any remnant population from the eastern North Atlantic (see Brown 1986).

Speculation that conception occurs between November and February is based upon estimates of a 12 or 13 mo gestation period by Best (1994) for southern right whales and sightings of North Atlantic neonates off the southeastern USA, which peak between December and February (Kraus et al. 1993, Kraus \& Rolland 2007, Hamilton \& Cooper 2010). Reproductive behavior is typically manifest in what are termed 'surface-active groups' (SAGs). These consist of a central female surrounded by competing males (Kraus \& Hatch 2001) who are probably attracted from some distance by her vocalizations (Parks 2003). The female swims on her back with her belly above the surface while males jostle for the opportunity for intercourse (Kraus \& Hatch 2001). Although there is a distinct peak in right whale calving, apparent courtship behavior in SAGs occurs throughout the year and throughout the right whales' known range (Winn et al. 1986, Parks et al. 2007). In an analysis of SAG sightings in which all participants were identified, only $47 \%$ of SAGs contained both an adult male and an adult female (Parks et al. 2007), suggesting that such behavior is also a general social activity for right whales (Best et al. 2003, Parks et al. 2007). Because observations of SAGs are not indicative of conception, characterizations other than behavior must be used to infer mating grounds.

Here, we provide support for a hypothesis that the central Gulf of Maine is a mating ground for North Atlantic right whales, by comparing proportions of females giving birth the following year-termed conceptive females - and the proportions of genetically identified fathers within each geographic region that the whales inhabit throughout the year. Candidate mating grounds are identified by the presence of significantly higher proportions of both conceptive females and fathers in regions inhabited by right whales during the inferred conception period.

\section{MATERIALS AND METHODS}

\section{Surveys}

Surveys for right whales along the eastern seaboard of the USA and Canada have been conducted by many organizations using both planes and boats since the late 1970s, and right whale sightings and individual identification data have been shared through common databases. The regions used in our analysis were delineated by the North Atlantic Right Whale Catalog (a photo-identification catalog of individual right whales, maintained at the New England Aquarium in Boston, USA), which enclose seasonal right whale sighting locations. The catalog used sightings data collected over a $15 \mathrm{yr}$ period to refine the contiguous regions originally drafted by Winn et al. (1986). The regions in our analysis included: (1) the Bay of Fundy, (2) the Great South Channel, (3) Jeffreys Ledge, (4) Massachusetts and Cape Cod Bays, (5) Roseway Basin, (6) the southeastern USA (defined as the waters off Georgia and Florida), and 
(7) central Gulf of Maine (bounded by $42^{\circ} 50^{\prime}$ to $43^{\circ} 45^{\prime} \mathrm{N}$ and $67^{\circ} 54^{\prime}$ to $68^{\circ} 54^{\prime} \mathrm{W}$ ) (Fig. 1). We drew the boundaries of the central Gulf of Maine region to enclose our winter sighting locations within the much larger Gulf of Maine region identified by the catalog and Winn et al. (1986).

From 2002 to 2008, surveys conducted by other research organizations were the source for right whale individual identification data from the southeastern USA, the Bay of Fundy, Roseway Basin, and Cape Cod Bay. The aerial surveys conducted by the National Oceanic and Atmospheric Agency (NOAA) covered Jeffreys Ledge, Massachusetts Bay, and the Great South Channel in conjunction with survey teams from other organizations. Right whale sighting data from the central Gulf of Maine from 2002 to 2008 were collected by NOAA aerial surveys exclusively. Surveys in all regions and by all organizations were typically conducted only on days with good visibility and winds forecast to be 15 knots or less. These shared criteria provided basic sighting condition quality control across regions.

From 2002 to 2006, the NOAA aerial surveys were broad scale and systematic to provide coarse coverage of all offshore waters north of $41^{\circ} 21^{\prime} \mathrm{N}$ and west of the Hague Line, the eastern boundary of the USA Exclusive Economic Zone. These surveys were conducted to chart right whale distribution throughout this extensive area (approximately $247000 \mathrm{~km}^{2}$ ) and to identify where right whale presence persisted outside of established habitat protection zones and time frames (Cole et al. 2007). From 2007 to 2008, the NOAA surveys covered areas where right whale presence was consistently detected during the broad-scale surveys. The primary objectives of these latter surveys were to establish the seasonality of right whale occupancy in the regions of the Gulf of Maine and to maximize the number of individual right whales photographed for mark-recapture analyses. These regions included the central Gulf of Maine, Jeffreys Ledge, and the Great South Channel. We flew a total of $162 \mathrm{~h}$ within the central Gulf of Maine region during the period 2002 to 2008, including time spent both on survey lines and circling for photographs. Sixtysix of these hours were flown during the primary period of right whale presence in the central Gulf of Maine (November through January); 60 of the $66 \mathrm{~h}$ were flown after 2004.

The NOAA surveys were flown at an altitude of 750 feet $(230 \mathrm{~m})$ and 100 knots $\left(185 \mathrm{~km} \mathrm{~h}^{-1}\right)$ using high-winged aircraft. An observer stationed on each side of the aircraft had a clear view of the water from directly in front to perpendicular to the aircraft's heading through large bubble windows. When right whales were sighted, the plane broke from the survey line and circled above the whales to collect photographs for individual identification. A digital SLR camera with a $300 \mathrm{~mm}$ lens was used from an open window near the back of the plane. Effort was made to photographically capture all right whales sighted during surveys. Similar methods were used during aerial surveys for right whales conducted by other organizations in the other regions. During boatbased surveys in the Bay of Fundy, Jeffreys Ledge, and Roseway Basin areas, a greater proportion of time was spent photographing whales.

\section{Individual identification}

Individual right whales were identified from photographs of their unique callosity patterns - cornified skin around the head colonized by light-colored Cyamidae - as well as scars and natural pigmentation patterns on the body (Payne et al. 1983, Kraus et al. 1986a). Images collected during surveys were compared and matched to individuals identified in

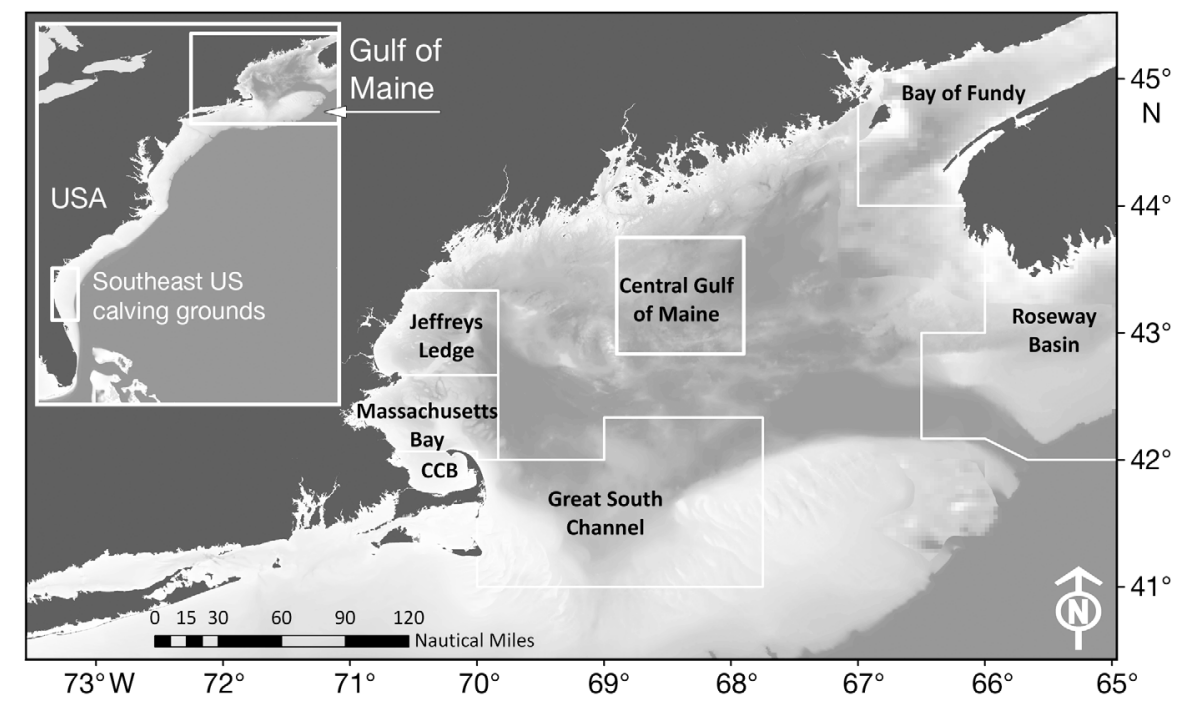

Fig. 1. Regions seasonally occupied by North Atlantic right whales Eubalaena glacialis. Sightings in Cape Cod Bay (CCB) are included within the Massachusetts Bay region in our analysis 
the North Atlantic Right Whale Catalog. Matches were made by visually comparing identifying features of the photographed whales to individuals documented in the catalog (Hamilton et al. 2007). Successful matches provided sighting histories and often information on the age, sex, and reproductive status of the photographed whales-information collected by a consortium of research organizations. A whale's age was established if it had been photographed and identified in its year of birth. Adults were defined as known-age whales $>8$ yr old, whales of unknown age with $>7 \mathrm{yr}$ sighting history (Hamilton et al. 1998), or females that had given birth, as indicated by consistent association with a calf (Knowlton et al. 1994). The sex of photographed individuals was determined either from pre-existing photographs of the genital region (after Payne \& Dorsey 1983), molecular analysis (Brown et al. 1991, 1994), or, for females, by extended calf accompaniment (Knowlton et al. 1994).

\section{Demographic comparisons among regions}

We hypothesized that a region serving as a mating ground would have a greater than expected proportion of reproductively successful individuals. Therefore, we calculated the proportions of females that became mothers the following winter versus all identified females, and the proportions of previously successful fathers versus all identified individuals within each region seasonally occupied by the whales from 2002 to 2008. These proportions also provided an adjustment for survey effort, which differed by an order of magnitude between some regions and likely had the greatest effect on the probability of photographically capturing individuals present. Any perception bias (i.e. differences in sighting conditions or platform performance; Marsh \& Sinclair 1989) between regions was mitigated by shared quality control measures and the summing of unique individuals sighted in each area each year, effectively averaging the conditions over the months of photographic capture effort for each region. Availability bias (in this instance behavioral differences between whales; Marsh \& Sinclair 1989) between regions or demographic groups was assumed to not have an effect on the proportions because the regions or groups would be affected equally.

We noted each identified individual present in each region each year. Successful fathers were identified through genetic analyses by Frasier et al. (2007), with additional paternity assignments by the same laboratory completed through 2006. Mothers were identified by consistent association with a calf (after Knowlton et al. 1994). We then scored females as conceptive for a 12 mo period from 1 March the winter before giving birth back a full year to 1 March 2 winters before giving birth, which in many cases extended the period back 2 calendar years prior to calving. For example, a female sighted with a calf in January 2009 would be scored as 'conceptive' during the period 1 March 2008 back to 1 March 2007 (Fig. 2). This extended conceptive period is not an established biological time frame in right whale life history, but a means of comparing the proportion of conceptive females in all regions with right whale sighting data. In contrast to the categorization of the females' reproductive status, fathers were scored as fathers in all years regardless of the year of birth of identified offspring. This 'once a dad, always a dad' metric was used because of the relatively low number of paternities assigned and the delay in paternity assignment (genetic samples need to be collected from both the calf and the father).

A different denominator was used for calculating the proportions of conceptive females because the variation in conceptive female counts is dependent upon the previous $2 \mathrm{yr}$ of a female's reproductive

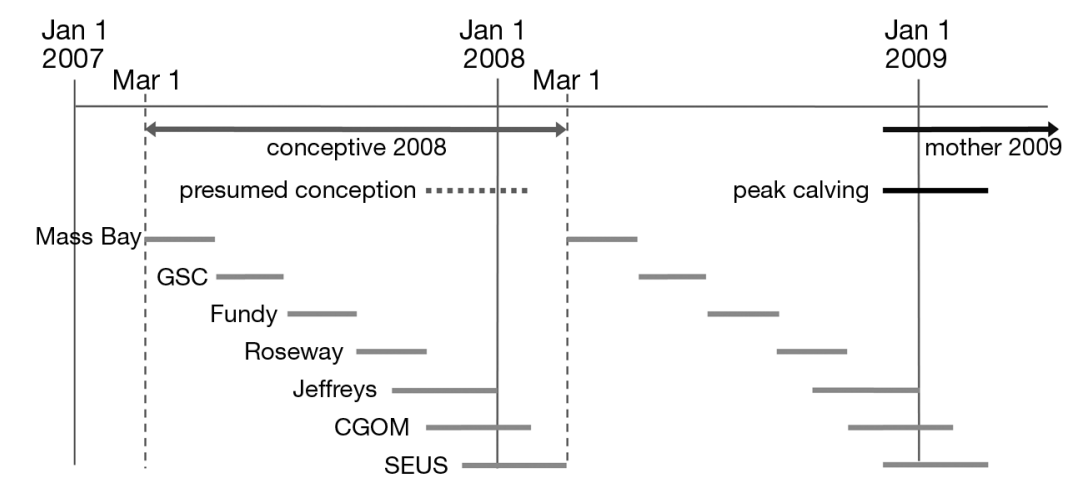

Fig. 2. Eubalaena glacialis. An example of the 2008 'conceptive' time frame used in our analysis overlaid with the North Atlantic right whales' presumed conception period based on estimates of gestation duration and the observed peak calving period. The lower solid grey lines illustrate the typical periods of peak numbers of individuals present in the regions delineated by the North Atlantic Right Whale Catalogue. CGOM: central Gulf of Maine; Fundy: Bay of Fundy; GSC: Great South Channel; Jeffreys: Jeffreys Ledge; Mass Bay: Massachusetts Bay; Roseway: Roseway Basin; SEUS: Southeast USA calving grounds 
cycle; conception follows a year of lactation and at least $1 \mathrm{yr}$ of rest. For males, the number of identified fathers was relatively constant, or at least there was very little identified biological variation, and newly identified fathers were rare. Known fathers were therefore a relatively constant fraction, and sample variance was reduced by using the larger denominator of all individuals identified in a region in a year.

We fitted generalized linear models (logistic regression models) to the proportions of conceptive females to all identified females and to the proportions of known fathers to all identified individuals, using year and region in different configurations as explanatory variables. Year was included as an explanatory variable because of annual variation in the population's reproductive output. The small sample-adjusted Akaike information criterion $\left(\mathrm{AIC}_{\mathrm{c}}\right)$ was used for model selection (Anderson 2008), and a $z$ test was used to identify significant differences between the central Gulf of Maine and the other regions.

\section{RESULTS}

Table 1 presents the numbers of unique female and male North Atlantic right whales Eubalaena glacialis sighted by all surveys in each region and each year during the study period. The NOAA surveys in the central Gulf of Maine photographed 212 different right whales over the $7 \mathrm{yr}$ period, representing roughly half the population (a minimum population estimate of 361 whales is based upon a count of recognized individuals known to be alive in 2005; Waring et al. 2010). Matches to the catalog found 102 males, including 26 known fathers. Forty-three females were identified, including 12 females who gave birth the winter after their visit to the central Gulf of Maine. Present were both females that in summer preferentially bring their calves to the Bay of Fundy and females that preferentially bring their calves to feeding grounds yet to be discovered.

Based on the $\mathrm{AIC}_{\mathrm{c}}$ applied to the generalized linear models of proportions of both known fathers to all identified individuals and conceptive females to all identified females, we found that only models with both region and year were plausible. The preferred model for fathers indicated by the $\mathrm{AIC}_{\mathrm{c}}$ scores coupled region with year as a continuous variable (Table 2). However, 2 other models had modest support relative to the preferred model. One of these used year as a continuous predictor, allowing different slopes for each year; the other used year as cate-
Table 1. Eubalaena glacialis. Numbers of unique female (F) and male (M) North Atlantic right whales sighted in each region by year. Individuals sighted between 1 January and 1 March are counted in previous years' tallies. Months of peak abundance are provided for each region. Totals include unique whales of unknown sex. CGOM: central Gulf of Maine; GSC: Great South Channel; SEUS: Southeast USA calving grounds

\begin{tabular}{|c|c|c|c|c|c|c|c|}
\hline & 2002 & 2003 & 2004 & 2005 & 2006 & 2007 & 2008 \\
\hline \multicolumn{8}{|c|}{ Massachusetts Bay (Mar-Apr) } \\
\hline $\mathrm{F}$ & 33 & 30 & 35 & 30 & 55 & 50 & 33 \\
\hline M & 33 & 25 & 31 & 27 & 62 & 62 & 71 \\
\hline Total & 70 & 57 & 70 & 59 & 135 & 131 & 120 \\
\hline \multicolumn{8}{|c|}{ GSC (May-Jun) } \\
\hline $\mathrm{F}$ & 71 & 75 & 62 & 102 & 35 & 64 & 28 \\
\hline M & 112 & 112 & 73 & 141 & 62 & 98 & 34 \\
\hline Total & 203 & 211 & 152 & 270 & 111 & 191 & 72 \\
\hline \multicolumn{8}{|c|}{ Bay of Fundy (Jul-Aug) } \\
\hline $\mathrm{F}$ & 59 & 52 & 43 & 75 & 47 & 51 & 48 \\
\hline M & 72 & 57 & 60 & 105 & 55 & 70 & 67 \\
\hline Total & 143 & 115 & 108 & 189 & 112 & 141 & 127 \\
\hline \multicolumn{8}{|c|}{ Roseway Basin (Aug-Sep) } \\
\hline $\mathrm{F}$ & 16 & 3 & 10 & 7 & 28 & 1 & 0 \\
\hline M & 28 & 14 & 49 & 12 & 86 & 0 & 1 \\
\hline Total & 51 & 20 & 69 & 21 & 127 & 1 & 1 \\
\hline \multicolumn{8}{|c|}{ Jeffreys Ledge (Oct-Dec) } \\
\hline $\mathrm{F}$ & 3 & 9 & 8 & 6 & 4 & 14 & 1 \\
\hline M & 7 & 12 & 13 & 3 & 33 & 27 & 27 \\
\hline Total & 10 & 21 & 21 & 10 & 42 & 48 & 30 \\
\hline \multicolumn{8}{|c|}{ CGOM (Nov-Jan) } \\
\hline $\mathrm{F}$ & 0 & 0 & 8 & 14 & 13 & 11 & 4 \\
\hline M & 1 & 0 & 17 & 50 & 25 & 40 & 11 \\
\hline Total & 1 & 0 & 29 & 75 & 42 & 58 & 19 \\
\hline \multicolumn{8}{|c|}{ SEUS (Dec-Feb) } \\
\hline $\mathrm{F}$ & 47 & 46 & 84 & 71 & 54 & 59 & 56 \\
\hline M & 33 & 34 & 82 & 66 & 41 & 52 & 32 \\
\hline Total & 83 & 84 & 179 & 162 & 113 & 132 & 98 \\
\hline
\end{tabular}

gorical variable interacting with the region. The preferred model showed that the proportion of fathers was higher than expected for the Jeffreys Ledge, central Gulf of Maine, and Roseway Basin regions (Fig. 3a), while in the southeastern USA the proportion was lower than average. Because the line was fitted, it extended through 2003 and 2004, when there was little survey effort and no fathers were sighted in the central Gulf of Maine region.

For conceptive females, the best model included additive effects of region and year treated as a categorical variable (Table 2). From the preferred model, the estimated fraction of conceptive females showed considerable annual variation (Fig. 3b). Although no conceptive females were sighted in the central Gulf of Maine from 2002 to 2004, that was likely due to a near complete lack of survey effort in this region 
Table 2. Eubalaena glacialis. Model selection statistics based on small sample-adjusted Akaike's information criterion $\left(\mathrm{AIC}_{\mathrm{C}}\right)$ values from generalized linear models predicting the proportions of individually identified right whales that were known fathers or conceptive females. Note that the evidence indicates that only models using both region and year are plausible $(\Delta$ AIC values $>5$ indicate considerably less support). Region + year (reg): region with year as a continuous variable and the same slope for all years; region $x$ year (reg): region with year as a continuous variable and different slopes for each year; region + year (factor): region with year as a categorical variable

\begin{tabular}{|lccc|}
\hline Model & $\mathrm{AIC}_{\mathrm{c}}$ & $\Delta \mathrm{AIC}$ & Weight \\
\hline Known fathers & & & \\
Region + year (reg) & 3020.8 & 0 & 0.491 \\
Region $\times$ year (reg) & 3021.9 & 1.1 & 0.283 \\
Region + year (factor) & 3022.6 & 1.8 & 0.200 \\
Region & 3026.6 & 5.9 & 0.026 \\
Region $\times$ year (factor) & 3059.1 & 38.3 & 0.000 \\
Year & 3108.5 & 87.7 & 0.000 \\
Year (reg) & 3192.5 & 171.7 & 0.000 \\
Conceptive females & & & \\
Region + year (factor) & 1338.5 & 0 & 0.998 \\
Region + year (reg) & 1351.8 & 13.3 & 0.001 \\
Region & 1356.3 & 17.9 & 0.000 \\
Region $\times$ year (reg) & 1356.6 & 18.2 & 0.000 \\
Region $\times$ year (factor) & 1371.5 & 33 & 0.000 \\
Year (factor) & 1417.5 & 79 & 0.000 \\
Year (reg) & 1427.3 & 88.8 & 0.000 \\
\hline
\end{tabular}

prior to 2005. The proportions of conceptive females were higher than expected for the central Gulf of Maine, Roseway Basin, Massachusetts/Cape Cod Bay, and the Great South Channel (Fig. 3b). Lower proportions than average were seen in the Bay of Fundy, Jeffreys Ledge, and the southeastern USA.

Comparing the results of both sexes identifies both Roseway Basin and the central Gulf of Maine as having significantly higher proportions of both known fathers and conceptive females. Jeffreys Ledge had a high proportion of fathers, but a low proportion of conceptive females. The southeastern USA had low proportions of both fathers and conceptive females.

\section{DISCUSSION}

Our discovery of North Atlantic right whale aggregations in the central Gulf of Maine during the presumed period of conception (November through January), coupled with significantly larger proportions of reproductively successful males and females, strongly suggests that this region is a mating ground for the species. The presence of females of 2 seasonal subpopulations - those that as calves were brought
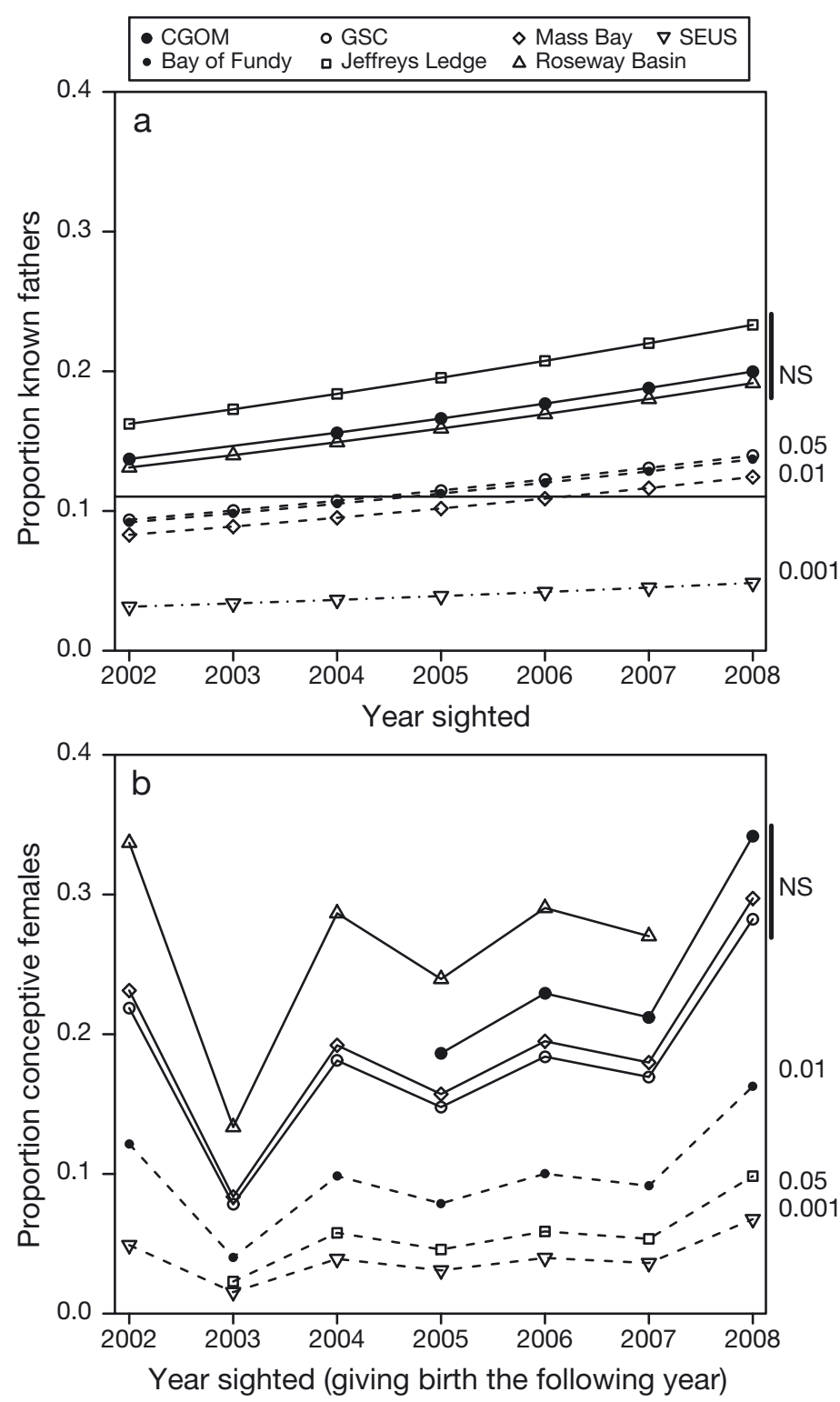

Fig. 3. Eubalaena glacialis. Probability estimates of finding (a) a known father or (b) a conceptive female among the whales identified in a region. $z$-test $p$-values on the right margin indicate region proportions that differ significantly from the central Gulf of Maine. The solid, slightly declining line in (a) is the expected proportion of fathers to all identified individuals, if region and year have no effect. CGOM: central Gulf of Maine; GSC: Great South Channel; Mass Bay: Massachusetts Bay; SEUS: Southeast USA calving grounds; NS: not significant

by their mothers to the Bay of Fundy, Nova Scotia, and those that were brought to other feeding grounds - suggests that this region is used by the entire population. Since this appears to be 1 interbreeding population, we would expect any mating ground to be shared. 
Right whale presence in the Jeffreys Ledge region also extends into the presumed conception time frame, with sighting numbers peaking between October and November (Weinrich et al. 2000). However, although we found a high proportion of known fathers in this area, the proportion of conceptive females was significantly lower there than in the other regions, with the exception of the Bay of Fundy and the southeastern USA. This echoes the findings of Brown et al. (2001) of spatial segregation of reproductive females from adult males and juveniles of both sexes. This finding also demonstrates the ability of our proportion metric to detect differences in the demography of regions outside of the southeastern US calving grounds during winter.

The proportions of reproductively successful individuals seen in the central Gulf of Maine were not significantly different from the proportions identified in Roseway Basin. However, the available acoustic detection and sighting data indicate that right whales occupy Roseway Basin in September and October and are absent by early November (Mitchell et al. 1986, Winn et al. 1986, Mellinger et al. 2007). Since neonate sightings peak between December and February, right whale presence on Roseway Basin falls outside of a 12 or 13 mo conception period derived from the gestation durations calculated by Best (1994) for southern right whales. However, if right whale gestation lasts closer to $14 \mathrm{mo}$, the peak conception period for North Atlantic right whales would extend back into October, when Roseway Basin had high detection rates.

A 14 mo gestation period for right whales is plausible. Fetus length data collected during modern whaling have provided gestation period estimates for many whale species (e.g. Lockyer 1984); however, the North Atlantic right whale was commercially extinct before modern whaling record-keeping, and few fetus data are available. The gestation period of the closely related southern right whale was estimated by Best (1994) using records of 221 fetuses collected during commercial whaling (208 of which came from illegal Soviet whaling in the early 1960s; see Tormosov et al. 1998), who applied Laws' (1959) adaptation of the Huggett \& Widdas' (1951) linear fetal growth model. The resulting estimates of 11.7 or 13.0 mo (357 or 396 d) do not represent a prediction interval, but were obtained by applying 2 different values to accommodate an initial, nonlinear phase of fetal growth (a $t_{0}$ of 0.1 or 0.2 , respectively). But Reese et al. (2001) argue that Laws' (1959) simple linear regression is problematic and underestimates the duration of gestation. To estimate the gestation period of bowhead whales Balaena mysticetus, Reese et al. (2001) used Laws' linear model with measurements from 23 fetuses and 3 neonates collected since 1969 at Point Barrow, Alaska, and estimated a gestation period of $13.2 \mathrm{mo}$. They calculated a $90 \%$ prediction interval of 11.0 to $17.8 \mathrm{mo}$. They also developed a Bayesian hierarchical nonlinear model (including neonates) that estimated a mean gestation period of 13.9 mo, with a $90 \%$ prediction interval of 12.8 to 15.0 mo. This later, more sophisticated model for bowheads suggests that right whale gestation may extend beyond the estimates of Best (1994), pushing the conception period - at least the initial weeks within the time frame of the right whales' presence over Roseway Basin.

But while sightings and acoustic data show right whales continue to occupy Roseway Basin through October, photographic captures of individuals there have not extended past September. Most of the fathers and all of the conceptive females identified in the Roseway Basin region were sighted between June and September, 15 to 17 mo before the start of the calving season. It is unknown if the higher proportions of reproductively successful individuals are still present in Roseway Basin when conceptions may start given a longer gestation period. In the central Gulf of Maine, both sightings and acoustic detections were highest from November through January (Bort 2011, T. V. Cole unpubl. data), which fits well within the peak conception period back-calculated from neonate sighting dates.

At least a few pregnancies begin outside of any estimated conception period. Neonates have been sighted as early in the calving season as 24 October and as late as 2 June (Watkins \& Schevill 1982, Patrician et al. 2009, New England Aquarium unpubl. data), and SAGs containing at least 1 adult male and 1 adult female have been recorded in all months of the year (Parks et al. 2007). Given that there is no evidence of delayed implantation in right whales (Lockyer 1984), neonates seen in April would have been conceived between February and April, outside the apparent period of right whale residency in either the central Gulf of Maine or Roseway Basin. However, sightings of neonates outside of the December through March calving period are atypical.

We acknowledge that conceptions may occur outside of the central Gulf of Maine region during the inferred conception period, and that this population may have other, as yet undiscovered, mating grounds. Survey effort was not sufficient to confirm the absence of any individual from another region, and a whale moving at an average speed of $79 \mathrm{~km} \mathrm{~d}^{-1}$ 
(Baumgartner \& Mate 2005) could have conceivably visited several of the identified regions within a week. Conceptions could have happened wherever a conceptive female and adult male were both present.

A longer time series of data is needed to establish the stability of this region as a seasonal habitat for right whales. Prior to 2005, there was relatively little marine mammal survey effort in the central Gulf of Maine during winter. The most comprehensive data component of the Winn et al. (1986) analysis of right whale distributional biology was collected by the Cetacean and Turtle Assessment Program (CeTAP; Winn 1982), which completed $<3 \mathrm{~h}$ of wintertime aerial survey effort within the $1^{\circ}$ quadrat that contains the region where we discovered right whale aggregations. If having an abundant food resource is an important element for a right whale mating ground, the whales' use of the central Gulf of Maine could collapse as it did for Roseway Basin during the 1990s. Patrician \& Kenney (2010) correlated the absence of right whales on Roseway Basin from 1993 through 1999 with low summer abundance of their primary prey in that region - older stages of the Calanus finmarchicus copepod (Baumgartner et al. 2003). Conversely, right whale sightings in the Bay of Fundy increased dramatically during this period (Patrician 2005). If food is the sole driver of right whale habitat selection in winter outside of the calving grounds, the location of any mating grounds would be dynamic in response to variations in prey abundance and quality. If the central Gulf of Maine's attraction to right whales is driven by social factors, such as providing a central mating arena for whales with different feeding area preferences, right whale presence in the region may be more stable across years.

Recovery of this Endangered species depends upon successful reproduction, but their current rate of reproduction is 3 times lower than expected compared to known rates from recovering populations of southern right whales (Best et al. 2001, Cooke et al. 2001). The reasons for this are not known, but may include a low level of genetic variability and/or inbreeding, effects of disease, food supply limitations, biotoxins, pollutants, or habitat loss (Knowlton et al. 1994, IWC 2001b, Kraus et al. 2001, 2007, Frasier et al. 2007). If right whale mating depends in part on the ability of females to call in males (Kraus \& Hatch 2001), increased noise pollution from coastal development may mask courtship vocalizations and thereby affect reproduction (Clark et al. 2009). Delineating the right whale's conception period and mating grounds is an important step towards addressing this potential impact.
Acknowledgements. Our analysis drew upon survey, individual identification, and high-resolution genetic data. Hundreds contributed. We gratefully acknowledge the contributions of the many unnamed scientists and interns. We also thank the creators and curators of the North Atlantic Right Whale Catalog - there is currently no better tool for exploring the ways of a population of whales. Dr. Richard Merrick made the NOAA aerial surveys possible. Christin Khan provided ArcGIS support. Dr. Mark Baumgartner provided insights on right whale motivation. Dr. Peter Corkeron's suggestions improved the manuscript. Dr. Scott Kraus provided needed encouragement.

\section{LITERATURE CITED}

Anderson DR (2008) Model based inference in the life sciences: a primer on evidence. Springer Science, New York, NY

Baumgartner MF, Mate BR (2005) Summer and fall habitat of North Atlantic right whales (Eubalaena glacialis) inferred from satellite telemetry. Can J Fish Aquat Sci 62: 527-543

Baumgartner MF, Cole TVN, Clapham PJ, Mate BR (2003) North Atlantic right whale habitat in the lower Bay of Fundy and on the SW Scotian Shelf during 1999-2001. Mar Ecol Prog Ser 264:137-154

> Best PB (1994) Seasonality of reproduction and the length of gestation in southern right whales, Eubalaena australis. J Zool (Lond) 232:175-189

Best PB, Brandão A, Butterworth DS (2001) Demographic parameters of southern right whales off South Africa. J Cetacean Res Manag 2(Spec Issue):161-169

Best PB, Schaeff CM, Reeb D, Palsbøll PJ (2003) Composition and possible function of social groupings of southern right whales in South African waters. Behaviour 140: 1469-1494

Bort JE (2011) Acoustic behavior of North Atlantic right whales in a potential winter mating ground: implications for management of human activity. MPhil thesis, College of the Atlantic, Bar Harbor, ME

Brown SG (1986) Twentieth-century records of right whales (Eubalaena glacialis) in the Northeast Altantic Ocean. In: Brownell RL, Best PB, Prescott JH (eds) Right whales: past and present status. IWC, Cambridge, p 121-127

Caswell H, Fujiwara M, Brault S (1999) Declining survival probability threatens the North Atlantic right whale. Proc Natl Acad Sci USA 96:3308-3313

Brown MW, Kraus SD, Gaskin DE (1991) Reaction of North Atlantic right whales (Eubalaena glacialis) to skin biopsy sampling for genetic and pollutant analysis. Rep Int Whal Comm Spec Issue 13:81-89

Brown MW, Kraus SD, Gaskin DE, White BN (1994) Sexual composition and analysis of reproductive females in the North Atlantic right whale, Eubalaena glacialis, population. Mar Mamm Sci 10:252-265

Brown MW, Brault S, Hamilton PK, Kenney RD and others (2001) Sighting heterogeneity of right whales in the western North Atlantic: 1980-1992. J Cetacean Res Manag 2(Spec Issue):245-250

Clark CW, Ellison WT, Southall BL, Hatch L, Van Parijs SM, Frankel A, Ponirakis D (2009) Acoustic masking in marine ecosystems: intuitions, analysis, and implication. Mar Ecol Prog Ser 395:201-222 
Cole TVN, Gerrior P, Merrick RL (2007) Methodologies of the NOAA National Marine Fisheries Service aerial survey program for right whales (Eubalaena glacialis) in the Northeast US, 1998-2006. US Dep Commer, Northeast Fish Sci Cent Ref Doc 07-02. www.nefsc.noaa.gov/ publications/crd/crd0702/ (accessed February 2012)

Cooke JG, Rowntree V, Payne R (2001) Estimates of demographic parameters for the southern right whales (Eubalena australis) observed off Peninsula Valdez, Argentina. J Cetacean Res Manag 2(Spec Issue):125-132

Frasier TR, Hamilton PK, Brown MW, Conger LA and others (2007) Patterns of male reproductive success in a highly promiscuous species: the endangered North Atlantic right whale. Mol Ecol 16:5277-5293

- Hamilton PK, Cooper LA (2010) Changes in North Atlantic right whale (Eubalaena glacialis) cow-calf association times and use of the calving ground: 1993-2005. Mar Mamm Sci 26:896-916

Hamilton PK, Mayo CA (1990) Population characteristics of right whales (Eubalaena glacialis) observed in Cape Cod and Massachusetts Bays, 1978-1986. Rep Int Whal Comm Spec Issue 12:203-208

Hamilton PK, Knowlton AR, Marx MK, Kraus SD (1998) Age structure and longevity in North Atlantic right whales Eubalaena glacialis and their relation to reproduction. Mar Ecol Prog Ser 171:285-292

Hamilton PK, Knowlton AR, Marx MK (2007) Right whales tell their own stories: the photo-identification catalog. In: Kraus SD, Rolland RM (eds) The urban whale: North Atlantic right whales at the crossroads. Harvard University Press, Cambridge, MA

Huggett AStG, Widdas WF (1951) The relationship between mammalian foetal weight and conception age. J Physiol 114:306-317

IWC (International Whaling Commission) (2001a) Report on the workshop on the comprehensive assessment of right whales. In: Best PB, Banister JL, Brownell RL, Donovan GP (eds) Right whales: worldwide status. IWC, Cambridge, $\mathrm{p}$ 1-60

IWC (International Whaling Commission) (2001b) Report on the workshop on status and trends of western North Atlantic right whales. In: Best PB, Banister JL, Brownell RL, Donovan GP (eds) Right whales: worldwide status. IWC, Cambridge, p 61-87

Kenney RD, Mayo CA, Winn HE (2001) Migration and foraging strategies at varying spatial scales in western North Atlantic right whales. J Cetacean Res Manag 2(Spec Issue):251-260

Knowlton AR, Brown MW (2007) Running the gauntlet: right whales and vessel strikes. In: Kraus SD, Rolland RM (eds) The urban whale: North Atlantic right whales at the crossroads. Harvard University Press, Cambridge, MA

Knowlton AR, Kraus SD, Kenney RD (1994) Reproduction in North Atlantic right whales (Eubalaena glacialis). Can J Zool 72:1297-1305

Kraus SD, Hatch JJ (2001) Mating strategies in the North Atlantic right whale (Eubalaena glacialis). J Cetacean Res Manag 2(Spec Issue):237-244

Kraus SD, Rolland RM (2007) Right whales in the urban ocean. In: Kraus SD, Rolland RM (eds) The urban whale: North Atlantic right whales at the crossroads. Harvard University Press, Cambridge, MA

Kraus SD, Moore KE, Price CA, Crone MJ, Watkins WA, Winn HE, Prescott JH (1986a) The use of photographs to identify individual North Atlantic right whales (Eubal- aena glacialis). In: Brownell RL, Best PB, Prescott JH (eds) Right whales: past and present status. IWC, Cambridge, p 145-151

Kraus SD, Prescott JH, Knowlton AR, Stone GS (1986b) Migration and calving of right whales (Eubalaena glacialis) in the western North Atlantic. In: Brownell RL, Best PB, Prescott JH (eds) Right whales: past and present status. IWC, Cambridge, p 139-144

Kraus SD, Kenney RD, Knowlton AR, Ciano JN (1993) Endangered right whales of the southwestern North Atlantic. Minerals Management Service, Herndon, VA

Kraus SD, Hamilton PK, Kenney RD, Knowlton AR, Slay CK (2001) Status and trends in reproduction of the North Atlantic right whale. J Cetacean Res Manag 2(Spec Issue):231-236

Kraus SD, Brown MW, Caswell H, Clark CW and others (2005) North Atlantic right whales in crisis. Science 309: 561-562

Kraus SD, Pace RM, Frasier TR (2007) High investment, low return: the strange case of reproduction in Eubalaena glacialis. In: Kraus SD, Rolland RM (eds) The urban whale: North Atlantic right whales at the crossroads. Harvard University Press, Cambridge, MA

Laws RM (1959) The foetal growth rates of whales with special reference to the fin whale, Balaenoptera physalus (Linn.). Discov Rep 29:281-308

Lockyer C (1984) Review of baleen whale (Mysticeti) reproduction and implications for management. Rep Int Whal Comm Spec Issue 6:27-50

Malik S, Brown MW, Kraus SD, Knowlton AR, Hamilton PK, White BN (1999) Assessment of genetic structuring and habitat philopatry in the North Atlantic right whale (Eubalaena glacialis). Can J Zool 77:1217-1222

Marsh H, Sinclair DF (1989) Correcting for visibility bias in strip transect aerial surveys of aquatic fauna. J Wildl Manag 53:1017-1024

Mellinger DK, Nieukirk SL, Matsumoto H, Heimlich SL and others (2007) Seasonal occurrence of North Atlantic right whale (Eubalaena glacialis) vocalizations at two sites on the Scotian Shelf. Mar Mamm Sci 23:856-867

Mitchell E, Kozicki VM, Reeves RR (1986) Sightings of right whales, Eubalaena glacialis, on the Scotian shelf, 1966-1972. In: Brownell RL, Best PB, Prescott JH (eds) Right whales: past and present status. IWC, Cambridge, p 83-107

Moore MJ, Knowlton AR, Kraus SD, McLellan WA, Bonde RK (2004) Morphometry, gross morphology and available histopathology in North Atlantic right whale (Eubalaena glacialis) mortalities (1970-2002). J Cetacean Res Manag 6:199-214

> Parks SE (2003) Response of North Atlantic right whales (Eubalaena glacialis) to playback of calls recorded from surface active groups in both the North and South Atlantic. Mar Mamm Sci 19:563-580

- Parks SE, Brown MW, Conger LA, Hamilton PK and others (2007) Occurrence, composition and potential functions of North Atlantic right whale (Eubalaena glacialis) surface active groups. Mar Mamm Sci 23:868-887

Patrician MR (2005) An investigation of the factors underlying the abandonment of the Roseway Basin feeding ground by the North Atlantic right whale (Eubalaena glacialis): 1993-1999. MS thesis, University of Rhode Island, Narragansett, RI

Patrician MR, Kenney RD (2010) Using the continuous plankton recorder to investigate the absence of North 
Atlantic right whales (Eubalaena glacialis) from the Roseway Basin foraging ground. J Plankton Res 32: 1685-1695

Patrician MR, Biedron IS, Esch HC, Wenzel FW and others (2009) Evidence of a North Atlantic right whale calf (Eubalaena glacialis) born in northeastern U.S. waters. Mar Mamm Sci 25:462-477

Payne R, Dorsey EM (1983) Sexual dimorphism and aggressive use of callosities in right whales (Eubalaena australis). In: Payne R (ed) Communication and behaviour of whales. AAAS Selected Symposium 76, Westview Press, Boulder, CO, p 295-329

Payne R, Brazier O, Dorsey EM, Perkins JS, Perkins VJ, Rowntree VJ, Titus A (1983) External features in southern right whales (Eubalaena australis) and their use in identifying individuals. In: Payne R (ed) Communication and behaviour of whales. AAAS Selected Symposium 76, Westview Press, Boulder, CO, p 371-445

Pettis H (2012) North Atlantic Right Whale Consortium 2012 annual report card. Report to the North Atlantic Right Whale Consortium, November 2012. www.narwc.org/ pdf/2012_Report_Card.pdf (accessed December 2012)

Reese CS, Calvin JA, George JC, Tarpley RJ (2001) Estimation of fetal growth and gestation in bowhead whales. J Am Stat Assoc 96:915-923

Reeves RR, Mead JG, Katona SK (1978) The right whale, Eubalaena glacialis, in the western North Atlantic. Rep Int Whal Comm 28:303-312

Reilly SB, Bannister JL, Best PB, Brown MW and others (2012) Eubalaena glacialis. In: IUCN (2012) IUCN Red List of Threatened Species, Version 2012.2. www.

Editorial responsibility: Simon Goldsworthy, West Beach, South Australia, Australia iucnredlist.org (accessed June 2013)

Schaeff CM, Kraus SD, Brown MW, White BN (1993) Assessment of the population structure of western North Atlantic right whales (Eubalaena glacialis) based on sighting and mtDNA data. Can J Zool 71:339-345

Tormosov DD, Mikhaliev YA, Best PB, Zemsky VA, Sekiguchi K, Brownell RL (1998) Soviet catches of southern right whales Eubalaena australis, 1951-1971. Biological data and conservation implications. Biol Conserv 86: 185-197

Waring GT, Josephson E, Maze-Foley K, Rosel PE (eds) (2010) U.S. Atlantic and Gulf of Mexico marine mammal stock assessments. NOAA Tech Memo NMFS-NE-219, Northeast Fisheries Science Center, Woods Hole, MA

Watkins WA, Schevill WE (1982) Observations of right whales, Eubalaena glacialis, in Cape Cod waters. Fish Bull 80:875-880

> Weinrich MT, Kenney RD, Hamilton PK (2000) Right whales (Eubalaena glacialis) on Jeffrey's Ledge: a habitat of unrecognized importance? Mar Mamm Sci 16:326-337

Winn HE (ed) (1982) A characterization of marine mammals and turtles in the mid- and North Atlantic areas of the U.S. outer continental shelf. Annual report for 1980. Cetacean and Turtle Assessment Program, University of Rhode Island, Kingston, RI. National Technical Information Service, Springfield, VA. www.ntis.gov

Winn HE, Price CA, Sorensen PW (1986) The distributional biology of the right whale (Eubalaena glacialis) in the western North Atlantic. In: Brownell RL, Best PB, Prescott JH (eds) Right whales: past and present status. IWC, Cambridge, p 129-138

Submitted: May 22, 2012; Accepted: March 2, 2013

Proofs received from author(s): June 17, 2013 